3. Басинский П. Мемуары - жанр сложный и благородный. Bonpocbl литературы / П. Басинский, 1999. № 1. С. 5-6.

4. Дзюба I. Туга за великою літературою: «Щоденники» Олекси Ізарського. Украӥна: культурна спадщина, національна свідомість, державність. 2012. С. 282-299.

5. Ізарський О. «Висмики» 3 щоденників. 1940-1980-і роки. Полтава: Динамік, 2006. 392 с.

6. Ільків А.В. Жанр щоденника в українській літературі другої половини XX - початку XXI століть: монографія / А. В. Ільків. Надвірна: ЗАТ Надвірнянська друкарня, 2010. 287 с.

7. Luckyj George S.N. Ukrainian literature in the twentieth century: A reader's guide. Toronto. University of Toronto Press, 1992. 136 pp.

DOI https://doi.org/10.30525/978-9934-588-90-7-26

\title{
ЗОБРАЖЕННЯ ПСИХІЧНОГО СТАНУ ПЕРСОНАЖА ЯК ДЖЕРЕЛО ПСИХОЛОГІЗМУ «НОВОЇ ДРАМИ»
}

\author{
Фока М. В. \\ доктор філологічних наук, доцент, \\ доцент кафедри лінгводидактики та іноземних мов \\ Центральноукраїнський державний педагогічний університет \\ імені Володимира Винниченка \\ м. Кропивницький, Україна
}

Епоха кінця XIX i початку XX століття позначена потужним розвитком театрального мистецтва, у якому відбувалося кардинальне, навіть революційне переосмислення п'єси, що відображено в самому терміні «нова драма», яким позначено драматичний твір зламу століть.

Вивченню феномену «нової драми» в літературі й драматургії присвячені праці Б. Бекермана, Л. Ветєліної, О. Журчевої, Г. Клочека, В. Панченка та ін. Визначено, що відкритий зовнішній конфлікт замінює прихований внутрішній; активну дію заступає внутрішня дія; ремарки, що пояснювали хід дії, спрямовані на створення настрою; деталі, звуки та паузи, які мали чітко виражений функційний характер, набувають особливого смислового навантаження; прості й зрозумілі діалоги та репліки стають на перший погляд незв'язними й нелогічними; символи, що фактично відсутні в реалістичних, так званих добре зроблених n'єсах, починають відігравати важливу роль. Усі ці зміни, які зазнав драматичний твір, демонструють уведення психологізму. 
Водночас розгляд особливостей зображення психічного стану головних героїв як джерела психологізму не досліджено вповні. У цьому полягає актуальність дослідження.

$\mathrm{У}$ цій доповіді ставимо за мету розкрити психологічний стан головної героїні п'єси визнаного новатора західноєвропейської «нової драми» Г. Ібсена «Ляльковий дім».

Драматург дуже тонко описує психологічну еволюцію головної героїні Нори: від, на перший погляд, безтурботної й легковажної до серйозної й глибокої особистості, від ніжної, слухняної й покірної до незалежної, сильної й навіть дещо бунтівної. У своїй книзі «Мистецтво драматургії» Ларош Егрі називає стани Нори, які вона поступово переживає: безвідповідальність і безпечність переходять у тривогу, тривога перетікає в страх, а страх - у відчай, потім, у кульмінаційний момент, вона ціпеніє, і далі, усвідомивши положення, у якому перебуває, приймає рішення [див.: 2, с. 70]. Відштовхуючись від запропонованих драматургом станів головної героїні, спробуймо детальніше простежити психологічну еволюцію Нори.

Стан безвідповідальності й безтурботності. У першій дії, із самого початку Нора постає як життєрадісна, весела й безтурботна. Наприклад, у той час, як іiі чоловік, адвокат Гельмер, наполягає на потребі заощаджувати (підвищену платню він отримає тільки через три місяці), Нора без вагань залишає посланцю крону за допомогу та 3 легкістю витрачає на подарунки й дрібниці. Уже тут приховано головний конфлікт п'єси: «Жодних боргів! - наголошує Гельмер. - Ніколи не позичати! На домашнє вогнище, засноване на позичках і боргах, лягає якась негарна тінь залежності» [1, с. 98-99]. По суті, у цих словах вирисовується конфлікт, з розвитком якого відбувається психологічна еволюція героїні.

Проте, як виявляється, Нора не така вже й легковажна: вісім років тому, на початку сімейного життя, вона позичила велику суму грошей, щоб вилікувати чоловіка від смертельної хвороби, і відтоді змушена віддавати борг, таємно заощаджуючи й підробляючи. Вона глибоко пишається своїм вчинком, у результаті якого вона не тільки врятувала життя чоловіку («Отож... я також маю чим пишатись і тішитися. Бо це я врятувала Торвальдові життя» [1, с. 107]), але й врятувала свій шлюб, приховавши правду («Торвальд зі своїм глибоко вкоріненим почуттям власної гідності... як гірко і принизливо було б для нього знати, що він мені чимось зобов'язаний. Це б цілком зіпсувало наші стосунки, наша злагоджена, щаслива родина вже не була б така, як тепер» [1, с. 109]).

Стан тривоги. Почуття тривоги посилюється в п’єсі поступово, але 3 незмінною динамічністю. Неспокій з'являється з появою Крогстада, того, у кого Нора позичила гроші та мусить їх віддавати. Уже сам його прихід змушує Нору тривожитись.

100 
Почуття тривоги посилюється, коли Крогстад, знаючи, що Нора підробила підпис батька на борговому зобов'язанні, починає шантажувати Нору, аби вона посприяла, щоб він залишився на службі, адже Гельмер хоче звільнити його. Тривожний стан посилюється поступово: спочатку Нора переконана в правильності вчинку, але вже починає сумніватися в цьому («Ет, що там!.. Хотів мене налякати! Не така я дурна. [...] Але... Нi, не може такого бути! Я ж зробила це 3 любові» [1, с. 123]), а потім почуття тривоги поглинає іiї повністю («Біда надходить. Таки не минає мене. Hi, ні, ні, не може цього статися, не повинно» [1, с. 141]).

Стан страху. Почуття тривоги перетікає в страх, який починає домінувати 3 моменту, коли лист опиняється в скриньці: «Лист у скриньці... Торвальде, Торвальде... Тепер нам немає рятунку!» [1, с. 144]. Тут почуття страху ще межує з почуттям надії, адже Нора ще намагається змінити ситуацію.

Стан відчаю. Почуття страху замінюється на відчай, коли лист потрапляє в руки Гельмеру. У момент, коли він іде читати лист, вона готова на крайні кроки, будучи щиро переконаною, що в цьому вихід: «Якщо мене не буде на світі, то ти вільний» [1, с. 162], - говорить Нора Гельмеру.

Стан оціпеніння. Коли ж Гельмер дочитує другого листа і розуміє, що вони врятовані (Крогстад повернув документ-зобов'язання), він відчуває радість, а Нора оціпеніння («Слухай же, Норо, ти ще наче не збагнула, що все минуло. Що таке?.. Ти ніби закам'яніла» [1, с. 164].), бо саме в цю хвилину, до неї поступово приходить прозріння, вона миттєво переосмислює своє життя.

Поштовхом до цього стає реакція чоловіка на ії вчинок, а скоріше, реакція, яку вона так і не отримала: Нора щиро вважала, що Гельмер візьме на себе іï провину, бо глибоко кохає іiі, як і вона його, тож, щоб цього не сталося, вона готова була накласти на себе руки, принести себе в жертву, аби врятувати його. Проте Гельмер вчинив зовсім протилежно: замість того, щоб, бодай, зрозуміти вчинок дружини, він обурено звинувачує ії (для нього вона лицемірка, брехунка й злочинниця, без побожності, моралі та відповідальності [1, с. 162], якій не можна довірити виховання дітей [1, с. 163]).

Вона усвідомлює, що все своє життя намагалася спочатку подобатися батьку, а згодом чоловіку, і в бажанні відповідати їхнім ідеалам загубила себе («Коли я жила вдома з татом, він висловлював мені свої погляди, тож я мала ті самі погляди. А коли в мене з'являлися інші, я їх приховувала, бо вони йому не сподобалися б. [...] Ти все влаштував на свій смак, і в мене ставав такий самий смак, чи я тільки вважала, що він такий, важко сказати... Думаю, і те, й те. Раз так, а раз інакше» 
[1, с. 166]). Її життя в мить знецінюється («Тепер, коли я оглядаюся назад, мені здається, що я жила тут жалюгідним життям, сяк-так перебивалася» $[1$, с. 166]) разом із знеціненням своєї особистості («Ви винні, що з мене нічого не вийшло» [1, с. 166]).

Прийняття рішення (рімучість). I Нора бачить для себе вихід: вона твердо переконана почати все 3 початку самостійно, із самовиховання, саморозвитку й самореалізації. Вона відчуває в собі сили та твердість духу: «Спершу треба виконати інше завдання. Подбати про своє виховання [...]. Мені самій треба взятися за це. [...] Я мушу бути сама, щоб зрозуміти себе і все навколо. [...] I я піду зараз же» [1, с. 167]. До того ж Нора повністю усвідомлює і можливі наслідки: «Я зовсім не знаю, що з мене вийде» [1, с. 171], - але впевнено йде уперед. Її впевненість у правильності рішення відчувається в розмові з чоловіком, Нора навіть акцентує: «Гельмер (насилу втримується). Це твоє тверде переконання? I ти дійшла до нього також при ясному розумі?

Нора. Так, тверде переконання, і я дійшла до нього при цілком ясному розумі» [1, с. 169].

Як точно зазначає драматург Ларош Егрі, розвиток Нори - це еволюція, а кульмінація - революція. Саме внутрішній конфлікт стає рушієм психологічних переживань героїні, а його розвиток психологічного росту [див.: 2, с. 70]. Головним рушієм внутрішнього конфлікту стає брехня, розкриття якої веде до прозріння. При тому такий детальний опис психологічних станів героїні створює психологізм твору.

Таким чином, психологізм «нової драми» створюється шляхом детального зображення психологічних станів персонажів. Зокрема, у п’єсі «Ляльковий дім» Г. Ібсен настільки детально описує еволюцію душевного стану головної героїні Нори, що читач/глядач $з$ легкістю вловлює перехід від однієї емоції до іншої. Це не лише стає рушієм сюжетної лінії, але змушує його жити, переживати й співпереживати, а це і $є$ вищою метою мистецтва.

\section{Література:}

1. Ібсен Г. Ляльковий дім: п’єси. Харків: Фоліо, 2011. 346 с.

2. Egri Lajos. The Art of Dramatic Writing: Its Basis in the Creative Interpretation of Human Motives. New York, London, Toronto, Sydney, Tokyo, Singapore: A Touchstone Book, 1972. 332 p. 